\title{
ANALISIS SITIRAN KARYA ILMIAH PUSTAKAWAN INDONESIA PADA JURNAL VISI PUSTAKA TAHUN 2008-2013 Sri Junandi*
}

\section{ABSTRACT}

The study aims: (1) to discover the scientific papersof librarians in the journal of Visi Pustaka published in 2008-2013, (2) to know the percentage of use of the scientific papersof librarians in the form of either articles or books, (3) to know the relevance and use of the title in the articlesand scientific papers cited in Visi Pustaka (4) to know the currency of the scientific papersof librarians cited in Visi Pustaka published in 2008-2013.

The study was descriptive, using Visi Pustaka published in 2008-2013 as a subject, and scientific paperswritten by librarians cited in Visi Pustaka as an object. Data were obtained through documentation and analyzed using citation analysis.

The result of the study showed: (1) there were 204 titles of scientific paperscited in Visi Pustaka, consisting of 78 titles in the form of textbooks and 126 in the form of articles. Out of 204 scientific papers, 109 were written by librarians comprising 31 titles in the form of textbooks and 78 titles in the form articles;(2)frequencyof book citationwas 11 times (5.39\%) written by Sulistyo-Basuki, 10 (4.90\%) by Lasa Hs, 8 (3.92\%) by Putu Laxman Pendit, 8 (3.92\%) by Abdul Rahman Saleh and Sutarno NS, 4 (1.96\%) by Sihabbudin Qalyubi, 3 (1.47\%) by Soeatminah and Wahyu Supriyanto, 2 (0.98\%) by Towa P. Hamakonda and Pawit M Yusup and 1 (0.49\%) by others. Meanwhile in terms of articles 14 times (6.86\%) were written by Sulistyo-Basuki, 8 (3.92\%) by Sri Purnomowati, 5 (2.45\%) by Putu Laxman Pendit, 3 (1,47\%) by 6 librarians namely Arif Surachman, Sri Hartinah, Hernandono, Neneng Komariah, Ida Fajar Priyanto, and Yaniasih, 2 (0.98\%) by 12 librarians and 1 (0.49\%) by 57 others; (3)there was relevance between subject of the title of the scientific papers and the title of the articles in Visi Pustaka publised in 2008-2013 whereby most of the cited works were used to support a study and some others were used as a reference (theoretical approach);(4) as many as 166 cited works (81.37\%) were current publications and 38 cited works (18.63) were not current.

Keywords: citation analysis, librarians, scientific papers

Pustakawan UGM

\section{PENDAHULUAN}

Salah satu kegiatan pustakawan menurut Kepmenpan No. 132 tahun 2002 yaitu pengembangan profesi yang diantaranya membuat karya tulis/karya ilmiah di bidang perpustakaan, dokumentasi dan informasi. Sementara itu bobot nilai angka kredit kegiatan membuat karya ilmiah berkisar 2-12,5 sesuai tingkatannya seperti dimuat dalam PerKaperpusnas RI No 2 Tahun 2008.

Visi Pustaka sebagai salah satu publikasi yang diterbitkan oleh Perpustakaan Nasional Republik Indonesia (PNRI), merupakan publikasi yang memuat artikel atau tulisan para pustakawan di Indonesia maupun pemerhati perpustakaan dari dalam maupun luar negeri. Tidak menutup kemungkinan artikel yang dimuat pada publikasi tersebut dirujuk oleh penulis lain, demikian pula sebaliknya penulis artikel pada Visi Pustaka juga merujuk dokumen lain di luar publikasi tersebut.

Beberapa alasan seseorang merujuk dokumen lain, diantaranya adalah: memberi penghormatan kepada penulis di bidangnya, identifikasi metodologi atau pendekatan teori, sebagai latar belakang atau bacaan bagi penulis yang ingin mengetahui lebih lanjut mengenai topik yang ditulis. Koreksi karya sendiri atau karya orang lain yang telah diterbitkan sebelumnya, memperkuat suatu temuan, dan sebagai panduan bagi mereka yang ingin mendalami topik tulisan yang dirujuk (Garfield, dalam Hartinah, 2002). Dokumen atau literaturliteratur yang dirujuk pada sebuah artikel 
kemudian dikumpulkan menjadi satu dan disebut dengan daftar pustaka, kepustakaan, bibliografi, atau referensi dan sebagainya.

Pada setiap penerbitan Visi Pustaka disertakan pula ketentuan atau petunjuk bagi penulis, diantaranya penulisan "daftar pustaka", hal ini menunjukkan bahwa daftar pustaka dibutuhkan dan memiliki peran dalam membuat sebuah artikel. Berkaitan dengan peranan tersebut, pertanyaan yang diajukan pada kajian ini adalah: bagaimana pemanfaatan karya ilmiah pustakawan yang dirujuk artikel-artikel yang dimuat Visi Pustaka periode 2008-2013.

Penulisan karya ilmiah tidak dapat melepaskan diri dari keharusan menggunakan berbagai sumber literatur bahan pustaka sebagai kutipan atau sitiran. Bahan pustaka itu digunakan untuk mendukung uraian penulisan, analisa atau sekurang-kurangnya dirangkaikan dengan buah pikiran peneliti menjadi suatu bangunan uraian teoritis. Biasanya sumber literatur yang dikutip atau disitir dicantumkan pada daftar pustaka/daftar referensi setiap karya ilmiah atau dalam suatu terbitan. Sitiran digunakan peneliti sebagai sandaran ilmiah untuk mengurangi subyektivitas sehingga tingkat obyektivitasnya tinggi dan meningkatkan kualitas karya ilmiahnya.

Dalam kajian informasi terhadap daftar kepustakaan salah satunya dikenal dengan analisis sitiran (citation analysis). Analisis sitiran digunakan untuk mengukur pengaruh intelektual keilmuan dari pengarang yang disitir, karena beberapa studi sitiran literatur digunakan untuk mengetahui karakteristik komunikasi ilmu pengetahuan dan banyak aspek kualitatif dari penelitian dan publikasi.

Pembahasan kajian sitasimenjelaskan bagaimana sebuah dokumen disitasi di dokumen lain karena dokumen yang disitasi itu menyediakan informasi yang relevan terhadap riset yang sedang dilakukan, misalnya dalam hal metode penelitian, landasan pemikiran, dan sebagainya. Sitasi dapat dilakukan sebagian ataupun menyeluruh, apabila diasumsikan bahwa semua sitasi bersifat serupa dalam hal sumbangannya kepada artikel pensitasi, maka ada beberapa kecenderungan yang dapat diperoleh:
1. Semakin sering sebuah dokumen dikutip, maka semakin besar dokumen itu memberi kontribusi informasi, dan semakin besar pengaruhnya pada penelitian yang sedang diinformasikan di dalam dokumen hasil sitasi. Ukuran dari pengaruh atau dampak (impact) ini adalah jumlah sitasi.

2. Berapa kali sebuah dokumen disitasi dalam satu rentang waktu tertentu menunjukkan berapa banyak informasi di dalam dokumen tersebut berguna untuk sebuah riset. Jika frekuensinya menurun, maka dokumen tersebut semakin tidak relevan, sampai akhirnya menjadi usang (obsolete).

adalah:

Rumusan masalah dalam kajian ini

a. Apa sajakah publikasi karya ilmiah pustakawan yang dimanfaatkan dalam artikel Visi Pustaka?

b. Berapa persentase pemanfaatan masingmasing publikasi karya ilmiah pustakawan dalam Visi Pustaka?

c. Apakah ada kesesuian antara subjek judul publikasi karya ilmiah pustakawan dengan judul artikel yang disitir pada Visi Pustaka, dan apa manfaatnya dalam artikel yang menyitirnya?

d. Bagaimana kemutakhiran publikasi ilmiah pustakawan yang dimanfaat-kan dalam Visi Pustaka?

Beberapa kajian analisis penggunan literatur untuk rujukan yang pernah dilakukan sebelumnya oleh Febriani (2015), Irianti (2013), Junandi (2010), Hasugian (2008), dan Istiana (2007). Mereka mengkaji penggunaan literatur pada karya-karya ilmiah berupa laporan penelitian, tesis dan disertasi. Sementara kajian penggunaan literatur pada jurnal antara lain dilakukan oleh Parlina (2012) pada jurnal kedokteran perguruan tinggi, dan Kurniawan (2012) pada Jurnal Fihris

Sedangkan asumsi dasar kajian ini, adalah bahwa semua publikasi ilmiah pustakawan yang dimanfaatkan dalam artikel Visi Pustaka benarbenar dimanfaatkan oleh penulis, baik dalam bentuk buku atau artikel. Pengertian "dimanfaatkan" maksudnya adalah bahwa 
publikasi ilmiah pustakawan yang disitir dan tercantum dalam daftar pustaka artikel dimanfaatkan dalam mendukung publikasi ilmiah tersebut .

\section{Fungsi Jurnal dalam Penelitian}

Sesuai dengan Keputusan Ketua Lembaga

Ilmu Pengetahuan Indonesia (LIPI)

No.81/Kep/H.10/1983 tentang TataTertib

Publikasi, jurnal adalah majalah yang memuat informasi mengenai hasil kegiatan di bidang ilmu penge-tahuan dan teknologi. Di dalam majalah ini berisi kumpulan pengetahuan baru, pengamatan empiris dan pengembangan gagasan atau usulan. Juga dijelaskan bahwa publikasi ini berfungsi sebagai media komunikasi yang sangat penting dalam ilmu pengetahuan karena memuat informasi terbaru. Bagi para ilmuwan, media ini dapat dipergunakan sebagai sarana untuk mengikuti perkembangan ilmu pengetahuan dan teknologi dalam bidangnya, dan sekaligus sebagai wadah bagi mereka untuk melaporkan hasil penemuan" serta buah pikirannya. Sementara itu menurut Sulistyo-Basuki (2002), jurnal merupakan: (a) media paling penting dalam komunikasi ilmiah, (b) merupakan pengetahuan publik, dan (c) arsip umum yang dapat dibaca oleh siapa saja.

Peningkatan kuantitas literatur ilmiah serta kemudahan memperoleh informasi sangat menunjang perkembangan ilmu pengetahuan. Ilmu pengetahuan terus meningkatkan produktivitas ilmuwan dalam melakukan penelitian, percobaan dan inovasi. Meningkatnya produktivitas karya ilmiah yang dihasilkan ilmuwan akan mendorong terbitnya media komunikasi ilmiah yang mengkomunikasikan hasil kegiatan ilmiah, dari seorang ilmuwan dengan ilmuwan lain pada masanya maupun masa sebelum dan sesudahnya. Media komunikasi yang dimaksud dapat berupa buku atau majalah ilmiah.

Komunikasi ilmiah yang dilakukan secara intensif seiring dengan perkembangan ilmu pengetahuan, dapat meningkatkan kerjasama antar ilmuwan dalam menghasilkan karya bersama. Karya bersama dua orang atau lebih yang menghasilkan karya bersama disebut kolaborasi. Kajian kolaborasi merupakan salah satu dari metode bibliometrika, yang bertujuan memberikan gambaran tentang cara mengukur dan menganalisa proses komunikasi terekam.

Komunikasi informasi pada perguruan tinggi yang dilakukan, merupakan serangkaian komunikasi ilmiah. Komunikasi ilmiah adalah sebuah sistem di mana penelitian dan kegiatan ilmiah lain yang dilakukan, ditulis, dievaluasi kualitasnya, disebarkan kepada komunitas ilmiah lain, dan dipertahankan untuk kepentingan masa yang akan datang. Komunikasi ilmiah formal dilakukan dengan melalui media-media penerbitan berkala, seperti jurnal ilmiah. Garvey, dalam Communication the Essense of Science, Pergamon Press, 1989 (Darmono, 1996:3) menyatakan bahwa komunikasi ilmiah melalui jurnal ilmiah merupakan hal yang amat penting dalam pengembangan ilmu pengetahuan. Melalui jurnal ilmiah, temuan baru dari peneliti dan ilmuwan dikomunikasikan ke masyarakat, guna mendapat tanggapan, dikembangkan dan disempurnakan oleh ilmuwan lain, sehingga kesempurnaan dan kebenaran ilmunya menjadi lebih baik. Jika ditarik lebih jauh, kehadiran berbagai jurnal ilmiah dalam masyarakat akademik juga merupakan investasi jangka panjang untuk memacu meningkatkan sumber daya manusia. Setiap penerbitan jurnal mempunyai kekuatan ganda, yaitu sebagai dokumentasi ilmu pengetahuan dan teknologi dan sebagai sarana penyebaran.

Menurut Sulistyo-Basuki (1995: 35-36) sebagai sebuah sistem komunikasi, maka komunikasi ilmiah formal memiliki keuntungan sebagai berikut:

1. Komunikasi formal bersifat terbuka sehingga kehadirannya lebih besar;

2. Penyebaran informasi relatif lebih luas dan lebih murah daripada komunikasi informal;

3. Informasi yang disimpan melalui komunikasi formal lebih permanen, menjadi "arsip umum" dan lebih mudah ditemukan;

4. Informasi yang disebarkan sudah melalui pemeriksaan reviewer majalah, karenanya sudah disesuaikan dengan standar disiplin ilmu yang bersangkutan. Demikian pula dengan cara penyajiannya termasuk penulisan arti dan daftar kepustakaan, sudah disesuaikan 
dengan pedoman yang berlaku untuk pembaca tertentu;

5. Komunikasi formal cenderung mengarah pada kepentingan pembaca luas.

Sedangkan kerugian komunikasi formal adalah seperti:

1. Usia informasi yang disebarkan melalui komunikasi formal umumnya lebih tua daripada informasi yang disebarkan melalui komunikasi infor-mal. Hal ini terjadi karena frekuensi penerbitan majalah tidaksama, adanya waktu tunggu untuk diterbitkan, dan redaksi harus menunggu naskah yang masuk;

2. Seringkali terjadi pengulangan inti makalah walaupun judulnya berbeda dan majalah yang memuatnya pun berlainan.

\section{Analisis Sitiran}

Analisis sitiran adalah kajian terhadap sejumlah sitiran atau rujukan yang terdapat dalam karya tulis ilmiah tertentu (Zulaikha, 2002:41). Sedangkan menurut Hartinah (2002) analisis sitiran adalah penyelidikan melalui data sitiran dari suatu dokumen, baik dokumen yang disitir maupun dokumen yang menyitir. Adapun hal-hal yang diselidiki antara lain: pengarang, subjek, tahun terbit, dan sumber dokumen (jumal, buku, dan jenis lain). Menurut Sulistyo-Basuki (1994: 177), analisis sitiran adalah analisis pada kepustakaan. Pada awalnya kajian berupa frekuensi sitiran, bahasa, tahun, jenis terbitan, dan pada saat ini berkembang pada kajian terhadap hubungan antara satu majalah dengan majalah lainnya, kajian terhadap ukuran sentralitas antara satu majalah dengan majalah lain, penelitian paro hidup bidang ilmu serta jaringan yang terbentuk akibat sitiran.

Beberapa alasan mengapa para ilmuwan selalu menyitir berbagai macam literatur dalam rangka penulisan karya mereka. Garfield (dalam Hartinah, 2002) mengemukakan bahwa seseorang penulis menyitir penulis lain karena:

1. Memberikan penghormatan kepada penulis atau karya di bidangnya.

2. Mengidentifikasi metodologi atau pendekatan teori.
3. Memberi latar belakang atau bacaan bagi mereka yang ingin mengetahui lebih lanjut topik yang sudah ditulis.

4. Mengoreksi karya sendiri atau karya orang lain.

5. Memberikan kritik terhadap karya yang telah terbit sebelumnya.

6. Memperkuat klaim suatu temuan.

7. Sebagai panduan bagi penulis lain yang akan mendalami topik tulisan yang disitir.

\section{Kemutakhiran Literatur}

Kemutakhiran informasi untuk setiap bidang ilmu berbeda. Namun yang sering menjadi masalah adalah tidak semua jurnal tercetak dapat segera di-manfaatkan oleh pengguna setelah diterbitkan, kecuali jika perpustakaan melanggan sendiri jurnal tersebut. Jurnal baru harus melalui beberapa tahapan pengolahan,selanjutnya setelah berada di ruang layanan, pengguna perlu menelusurnya terlebih dahulu melalui indeks, katalog atau sarana referensi lainnya untuk dapat memanfaatkannya.

Seiring dengan kemajuan teknologi informasi dan komunikasi maka jarak, ruang, dan waktu menjadi hampir tidak ada batasan. Pola perilaku pengguna perpustakaan dalam mencari informasi perlu mengikuti perubahan tersebut dan perpustakaan harus siap jika diperlukan. Perpustakaan harus terhubung ke jaringan internet karena banyak informasi yang dapat dicari di internet, salah satunya adalah jurnal elektronis.

Ketersediaan informasi mutakhir sangat dibutuhkan oleh peneliti untuk mendukung kegiatan penelitian. Dibandingkan dengan buku/monograf, jurnal ilmiah memuat informasi yang lebih mutakhir karena berisi artikel-artikel hasil penelitian terbaru dan aktual. Pembanding penelitian seharusnya lebih mutakhir, sehingga peneliti sebaiknya menyitir artikel jurnal terbaru sesuai dengan bidang ilmunya.

Pada dasarnya kemutakhiran literatur yang dirujuk dalam suatu karya tulis ilmiah mencerminkan kekinian (actuality) informasi dari karya tulis tersebut (Hermanto, 2004:1). Menurut Pedoman Terbitan Berkala Ilmiah Tahun 2014, dinyatakan bahwa kemutakhiran referensi (pustaka acuan) merupakan salah satu aspek substansial dalam penilaian akreditasi jurnal 
ilmiah. Dalam instrumen ini ditegaskan bahwa kemutakhiran referensi tersebut dengan melihat proporsi terbitan sepuluh tahun terakhir.

Meskipun kualitas sebuah karya ilmiäh atau penelitian tidak terkait langsung dengan kemutakhiran literatur yang dirujuk, namun literatur-literatur terbaru yang digunakan sebagai rujukan diharapkan akan membuka cakrawala baru dalam pembahasan hasil penelitian. Dengan demikian penggunaan literatur yang sudah tidak mutakhir (out of date) sebagai rujukan dapat diterima sepanjang data atau informasi yang dimiliki relevan dengan topik tersebut, atau belum ada literatur baru yang lebih baik atau lebih lengkap dari literatur tersebut (Hermanto, 2004:3).

Menurut Milkkailov (dalam Herli-na, 1995:36), penggunaan literatur yang relatif tidak mutakhir sebagai rujukan dikarenakan adanya kekhususan informasi, misalnya mengenai publikasi orisinil yang menjadi syarat konsep atau ide serta metodologi.

Berdasarkan uraian di atas dapat disimpulkan bahwa kemutakhiran informasi tidak menjadi syarat mutlak seorang peneliti dalam merujuk informasi, sepanjang informasi yang dirujuk sesuai atau relevan dengan subjek yang merujuk, meskipun informasi tersebut tidak mutakhir dan belum ada informasi yang baru dan lengkap dari literatur tersebut.

Kajian menggunakan pedoman mengukur kemutakhiran informasi yang digunakan pada Pedoman Akreditasi Terbitan Berkala Ilmiah yang menegaskan bahwa kemutakhiran referensi derigan melihat proporsi terbitan sepuluh tahun terakhir.

\section{METODE PENELITIAN}

Kajian yang dilaksanakan adalah penelitian deskriptif, dengan maksud mengetahui publikasi ilmiah pustakawan yang dimanfaatkan (disitir), persentase pemanfaatan publikasi ilmiah pustakawan yang disitir pada artikel Jurnal Visi Pustaka.

Pada kajian ini metode pengumpulan data yang dipergunakan, yaitu metode dokumentasi. Metode dokumentasi, karena pada penelitian ini data diperoleh dari daftar pustaka atau sitiran dalam artikel ilmiah yang dimuat pada artikel Jumal Visi Pustaka.

Selanjutnya langkah-langkah yang dilakukan dalam pengumpulan data adalah sebagai berikut:

a) Mengumpulkan semua edisi dan volume Visi Pustaka tahun 2008-2013, dengan mendownload http://www.pnri.go.id/MajalahOnline.aspx.

b) Memeriksa setiap Volume dan Nomor majalah yang telah dikumpulkan.

c) Memeriksa dan mengumpulkan judul artikel dan daftar pustaka.

d) Setelah data terkumpul, selanjutnya dibuatkan lembar kerja dalam bentuk tabel dengan menggunakan Microsoft Excel. Untuk keperluan tersebut dibuat lembar kerja yang memuat lima kolom meliputi: (1) kolom nomor urut, (2) kolom Nama Pustakawan, (3) kolom judul buku/artikel yang disitir, (4) kolom jenis artikel yang dibagi menjadi dua kolom yaitu buku dan artikel, dan (5) tahun terbit.

e) Membuat tabel yang terdiri atas empat kolom, yaitu (1) kolom nomor urut, (2) kolom pustakawan yang kelompok buku dan artikel, (3) kolom frekuensi disitir, (4) kolom persentase disitir.

f) Membuat tabel yang terdiri atas tiga kolom, meliputi: (1) kolom nomor urut, (2) kolom judul buku dan artikel yang disitir, (3) kolom tahun terbit

Setelah data terkumpul kemudian penulis melakukan kegiatan analisis data yang terdiri beberapa tahap:

a. Melakukan koreksi terhadap instrumen yang telah diisi pada lembar kerja (Microsoft Excel).

b. Mengelompokkan data publikasi ilmiah pustakawan berdasarkan jenis buku atau artikel, dan tahun terbit.

c. Mencatat semua judul buku dan artikel yang tercantum pada daftar pustaka dalam artikel majalah.

d. Hasil penentuan peringkat tersebut kemudian dilakukan penghitungan persentase dan disajikan dalam bentuk tabel. 
e. Kemudian masing-masing tabel dilakukan analisis secara deskriptif.

f. Merangking semua judul publikasi.ilmiah pustakawan pada poin (d) berdasarkan tahun terbitan untuk mengetahui kemutakhiran publikasi ilmiah pustakawan yang disitir dalam Visi Pustaka.

g. Kemutakhiran publikasi ilmiah pustakawan adalah dengan melihat proporsi sepuluh tahun terakhir publikasi ilmiah pustakawan yang disitir dalam Visi Pustaka.

Semua perhitungan persentase menggunakan rumus dari Kerlinger (1990:246) sebagai berikut:

Persentase $=$ proporsi $\times 1000$

Keterangan:

Proporsi merupakan pecahan yang

Pembilangnya adalah satu di antara dua frekuensi atau lebih.

Penyebutnya adalah seluruh frekuensi terobservasi.

\section{HASIL DAN PEMBAHASAN}

Berdasarkan hasil perhitungan data diperoleh sebanyak 204 judul publikasi ilmiah pustakawan baik bentuk buku dan artikel yang telah dimanfaatkan atau disitir dalam Visi Pustaka 2008-2013. Apabila ditinjau dari prosentase jenis yaitu bentuk buku dimanfaatkan atau disitir sebanyak 78 atau $38,24 \%$ dan dalam bentuk artikel sebanyak 126 atau 61,76\%.

Berdasarkan analisis data dari 78 judul buku yang telah dimanfaatkan dalam penulisan artikel, ada 31 orang pustakawan yang karya ilmiahnya diman-fatkan. Hasil perhitungan menunjukkan terdapat 10 pustakawan yang karya ilmiahnya disitir sebanyak 2-11 (0,98-5,39\%), sedangkan 20 pustakawan yang lain disitir 1 $(0,49 \%)$. Hal tersebut menunjukkan bahwa publikasi ilmiah pustakawan dalam bentuk buku telah memberikan manfaat dan kontribusi dalam penulisan artikel Visi Pustaka 2008-2013 sebesar 78 judul $(38,24 \%)$.

\section{Tabel 1}

Frekuensi pemanfaatan publikasi ilmiah pustakawan dalam bentuk buku

\begin{tabular}{|c|c|c|c|}
\hline No & Pustakawan & $\begin{array}{l}\text { Jumlah } \\
\text { Sitiran }\end{array}$ & Prosentase \\
\hline 1 & Sulistyo-Basuki & 11 & $5.39 \%$ \\
\hline 2 & Lasa Hs & 10 & $4.90 \%$ \\
\hline 3 & Pendit, Putu Laxman & 8 & $3.92 \%$ \\
\hline 4 & Saleh, Abdul Rahman & 7 & $3.43 \%$ \\
\hline 5 & Sutarno NS. & 7 & $3.43 \%$ \\
\hline 6 & Qalyubi, Sihabbudin & 4 & $1.96 \%$ \\
\hline 7 & Soeatminah & 3 & $1.47 \%$ \\
\hline 8 & $\begin{array}{l}\text { Supriyanto, Wahyu dan } \\
\text { Ahmad Muhsin }\end{array}$ & 3 & $1.47 \%$ \\
\hline 9 & $\begin{array}{l}\text { Towa P. Hamakonda } \\
\text { dan J.N.B. Tairas }\end{array}$ & 2 & $0.98 \%$ \\
\hline 10 & Yusup, Pawit M. & 2 & $0.98 \%$ \\
\hline 11 & $\begin{array}{l}\text { Darmawan, Rahman } \\
\text { dan Zulfikar Zen }\end{array}$ & 1 & $0.49 \%$ \\
\hline 12 & Darmono & 1 & $0.49 \%$ \\
\hline. & 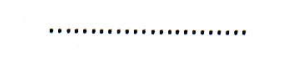 & $\ldots \ldots$. & .............. \\
\hline. & 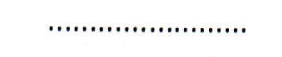 & ......... & …......... \\
\hline .. & ………............... & (........ & …......... \\
\hline 29 & Wijayanti, Luki & 1 & $0.49 \%$ \\
\hline 30 & $\begin{array}{l}\text { Yulia, Yuyu dan } \\
\text { B.Mustafa }\end{array}$ & 1 & $0.49 \%$ \\
\hline \multirow[t]{2}{*}{31} & Zen, Zulfikar & 1 & $0.49 \%$ \\
\hline & Jumlah & 78 & $38,24 \%$ \\
\hline
\end{tabular}

Sumber Data Primer yang diolah, 2015.

Hasil perhitungan juga memperoleh data yaitu sebanyak 126 judul publikasi karya ilmiah pustakawan dalam bentuk artikel dimanfaatkan dalam penulisan artikel Visi Pustaka sebesar $61,76 \%$. Hasil analisis data dari 126 judul tersebut merupakan hasil publikasi dari 78 pustakawan, selanjutnya terdapat sebanyak 21 pustakawan karya ilmiahnya memperoleh sitiran 2-14 $(0,98-6,86 \%)$ dan 57 pustakawan yang lain disitir $1(0,49 \%)$. 
Tabel 2

Frekuensi pemanfaatan publikasi ilmiah pustakawan dalam bentuk artikel

\begin{tabular}{|c|c|c|c|}
\hline No & Pustakawan & $\begin{array}{l}\text { Jumlah } \\
\text { Sitiran }\end{array}$ & Prosentase \\
\hline 1 & Sulistyo-Basuki & 14 & $6.86 \%$ \\
\hline 2 & Purnomowat, Sri & 8 & $3.92 \%$ \\
\hline 3 & Pendit, Putu Laxman & 5 & $2.45 \%$ \\
\hline 4 & Arlf Surachman & 3 & $1.47 \%$ \\
\hline 5 & Hartinah, Sri & 3 & $1.47 \%$ \\
\hline 6 & Hernandono & 3 & $1.47 \%$ \\
\hline 7 & Komarlah, Neneng & 3 & $1.47 \%$ \\
\hline 8 & Prlyanto, Ida Fajar & 3 & $1.47 \%$ \\
\hline 9 & Yanlasih et al. & 3 & $1.47 \%$ \\
\hline 10 & Achmad & 2 & $0.98 \%$ \\
\hline 11 & Ajil, R.F. & 2 & $0.98 \%$ \\
\hline 12 & Andriaty, Etty & 2 & $0.98 \%$ \\
\hline " & …….......................... & ......... & (............ \\
\hline .. & 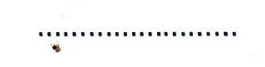 & ......... & $\ldots \ldots \ldots \ldots$ \\
\hline. & .......................... & ......... & …....... \\
\hline 76 & Yamini, Rachmi & 1 & $0.49 \%$ \\
\hline 77 & Yudha Prawira, Donni & 1 & $0.49 \%$ \\
\hline \multirow[t]{2}{*}{78} & Zulaikha, Sri Rohyanti & 1 & $0.49 \%$ \\
\hline & Jumlah & 126 & $61,76 \%$ \\
\hline
\end{tabular}

Sumber Data Primer yang diolah, 2015.

Kesesuaian antara Subjek Judul Artikel dengan Judul Artikel Publikasi Ilmiah Pustakawan yang Disitir

Hasil kajian pemanfaatan publikasi ilmiah pustakawan dalam penulisan artikel Jumal Visi Pustaka, secara keseluruhan menunjukkan adanya relevansi antara subjek judul publikasi ilmiah pustakawan dengan judul artikel yang disitir dalam jurnal Visi Pustaka. Hal ini diperkuat dengan adanya kesesuaian antara subjek artikel dengan judul artikel rujukan yang disitir. Telaah ke dalam isi artikel diketahui bahwa sebagian besar rujukan tersebut cenderung lebih banyak dimanfaatkan dalam hal pendekatan teori dan diskusi hasil kajian terutama untuk memperkuat hasil temuannya.
Berdasarkan hasil kajian dari ke 204 judul publikasi ilmiah pustakawan baik dalam bentuk buku maupun artikel, telah dimanfaatkan dalam Jurnal Visi Pustaka sebagian besar sebagai pendukung hasil kajian (diskusi hasil kajian) dan sebagian kecil sebagai bahan bacaan (pendekatan teori).

\section{Kemutakhiran Publikasi Ilmiah Pustakawan yang Disitir}

Seperti telah dikemukakan pada landasan teori, bahwa kemutakhiran literatur yang dirujuk dalam suatu karya tulis ilmiah mencerminkan kekinian (actuality) informasi dari karya tulis tersebut (Hermanto, 2002:1). Pada kajian ini untuk menentukan kemutakhiran literatur publikasi karya ilmiah pustakawan yang disitir dalam Jurnal Visi Pustaka, berpedoman pada Pedoman Akreditasi Terbitan Berkala Ilmiah 2014. Pada pedoman adalah kemutakhiran bahan pustaka yang dipergunakan sebagai rujukan dan kemutakhiran bahan pustaka yang dipergunakan dengan melihat proporsi terbit sepuluh tahun terakhir.

Tabel 3

Kemutakhiran Publikasi Karya Ilmiah Pustakawan yang Disitir

\begin{tabular}{cccc}
\hline No. & $\begin{array}{c}\text { Kemutakhiran } \\
\text { (Tahun) }\end{array}$ & $\begin{array}{c}\text { Jumlah } \\
\text { Sitiran }\end{array}$ & $\begin{array}{c}\text { Prosentase } \\
\text { (\%) }\end{array}$ \\
\hline 1 & $0-2$ & 17 & $8.33 \%$ \\
2 & $3-4$ & 36 & $17.65 \%$ \\
3 & $5-6$ & 59 & $28.92 \%$ \\
4 & $7-8$ & 35 & $17.16 \%$ \\
5 & $9-10$ & 19 & $9.31 \%$ \\
6 & $11-15$ & 18 & $8.82 \%$ \\
7 & $16-20$ & 9 & $4.41 \%$ \\
8 & $21-25$ & 9 & $4.41 \%$ \\
9 & $26-30$ & 2 & $0.98 \%$ \\
10 & $>30$ & 0 & $0.00 \%$ \\
& Jumlah & 204 & $100 \%$ \\
\hline
\end{tabular}

Sumber Data primer yang diolah, 2015.

Berdasarkan pedoman tersebut, hasil analisis data diperoleh bahwa ada 109 pustakawan yang publikasi karya ilmiahnya baik dalam bentuk buku dan artikel yang telah 
dimanfaatkan atau disitir dalam Jurnal Visi Pustaka 2008-2013 sebanyak 204. Apabila ditinjau dari kemutakhirannya yaitu sebesar $81,37 \%$ publikasi karya ilmiah pustakawan atau setara dengan 166 sitiran termasuk dalam kategori mutakhir (sepuluh tahun terakhir) yang terdiri atas $0 \mathrm{~s} / \mathrm{d} 2$ tahun sebanyak 17 artikel $(8,33 \%), 3 \mathrm{~s} / \mathrm{d} 4$ tahun sebanyak 36 artikel $(17,65 \%), 5 \mathrm{~s} / \mathrm{d} 6$ tahun sebanyak 59 artikel $(28,92 \%), 7$ s/d 8 tahun sebanyak 35 artikel $(17,16 \%)$ dan $9 \mathrm{~s} / \mathrm{d} 10$ tahun sebanyak 19 artikel $(9,31 \%)$.

Publikasi ilmiah pustakawan sebesar $18,63 \%$ atau setara dengan 38 sitiran termasuk dalam kategori tidak mutakhir (lebih dari sepuluh tahun terakhir) yang terdiri $11 \mathrm{~s} / \mathrm{d} 15$ tahun sebanyak 18 artikel $(8,82 \%), 16 \mathrm{~s} / \mathrm{d} 20$ tahun sebanyak 9 artikel (4,41\%), $21 \mathrm{~s} / \mathrm{d} 25$ tahun sebanyak 9 artikel $(4,41 \%), 26 \mathrm{~s} / \mathrm{d} 30$ tahun sebanyak 2 artikel $(0,98 \%)$ dan lebih 30 tahun sebanyak tidak ada $(0 \%)$.

\section{Simpulan}

Berdasarkan hasil kajian yang telah terurai di atas diperoleh beberapa simpulan sebagai berikut:

a. Di dalam Jurnal Visi Pustaka 2008-2013, telah dimanfaatkan publikasi karya ilmiah pustakawan sebanyak 103 judul.

b. Persentase pustakawan yang publikasi ilmiahnya dimanfaatkan pada Jurnal Visi
Pustaka, peringkat pertama diperoleh Sulistyo-Basuki dengan perolehan sitiran sebanyak 25 sitiran yang terdiri dari 11 buku dan 14 artikel atau (12,25\%). Sedangkan rangking terendah diterima oleh 126 pustakawan, dimana masing-masing memperoleh satu kali sitiran $(0,49 \%)$.

c. Terdapat sebanyak 126 judul publikasi ilmiah pustakawan yang telah dimanfaatkan dalam Jurnal Visi Pustaka 2008-2013 dan ke 126 publikasi ilmiah pustakawan tersebut, ada kesesuaian antara subjek judul artikel dengan judul artikel yang disitir dalam Jurnal Visi Pustaka 2008-2013. Publikasi ilmiah pustakawan yang disitir tersebut sebagian besar dimanfaatkan sebagai pendukung hasil kajian (diskusi hasil kajian) dan sebagian kecil sebagai bahan bacaan (pendekatan teori).

d. Secara deskriptif hasil penelitian menunjukkan bahwa kemutakhiran publikasi karya ilmiah pustakawan yang telah dimanfaatkan dalam Jurnal Visi Pustaka 2008-2013, adalah $\mathbf{8 1 , 3 7 \%}$ termasuk kategori mutakhir (sepuluh tahun terakhir) setara dengan 166 sitiran dan $\mathbf{1 8 , 6 3 \%}$ tidak termasuk dalam kategori mutakhir (lebih dari sepuluh tahun terakhir) setara dengan 38 sitiran. 


\section{DAFTAR PUSTAKA}

American Library Association. ALA's Guide to the Evaluation of Library Collections.

Keputusan Menteri Pendayagunaan Aparatur Negara No.

132/KEP/M.PAN/12/2002Tentang

Jabatan Fungsional Pustakawan dan Angka Kreditnya". Jakarta.

Undang-Undang Republik Indonesia No. 43 Tahun 2007 Tentang Perpustakaan. Jakarta: Sekretariat Negara.

Perpustakaan Nasional RI, 2010. "Peraturan Kepala Perpustakaan Nasional RI No. 2 Tahun 2008 Tentang Petunjuk Teknis Jabatan Pustakawan dan Angka Kreditnya". Jakarta: Perpustakaan Nasional.

Kementerian Pendidikan Nasional, 2014. Pedoman Akreditasi Terbitan Berkala Ilmiah. Jakarta: Kementrian Pendidikan Nasional.

Budd, J.M. 1990. "Higher Education Literature: Characteristic of Cita-tion Patterns", The Journal of Higher Education. Vol. 61 (1):84-97.

Ching, JTY., and Chennupati, KR. 2002. "Collection Evaluation through Citation Analysis Techniques: A Case Study of the Ministry of Education, Singapore", Library Review, Vol. 51 (18/9):398-405 .

Darmono, 1996. Komunikasi Ilmiah Melalui Jurnal Mengapa Kita Tertinggal?.http://www.hamline.edu/a pakabar/basisdata/1996/08/02/0050.ht ml, diakses pada tanggal 14 April 2009, pukul 14.05

Febriani, R. 2015. Analisis Sitiran Terhadap Artikel Dalam Majalah Perpustakaan Visi Pustaka Volume 12 Tahun 2010 -Volume 15 Tahun2013.Thesis. Semarang. Program Pascasarjana Universitas Diponegoro.

Hasugian, J. 2008. Analisis Sitiran Terhadap Disertasi Program Doktor (S3) Ilmu Hukum Program Pascasarjana
Universitas Sumatera Utara.

Hermanto. 2004. "Kajian Kemutakhiran Referensi " Artikel Ilmiah pada Beberapa Jurnal Ilmiah Penelitian Pertanian", Jurnal Perpustakaan Pertanian, Vol. 13, (1):1-6.

Irianti, 2013. Pola Pengunaan Literatur dan Usia Literatur pada Media Informasi (Kajian Analisis Sitiran). Berkala Ilmu Perpustakaan dan Informasi Volume

Istiana, P. 2007. Analisis sitiran terhadap skripsi juruan kartografi dan penginderaan jauh Fakultas Geografi tahun 2005 dan ketersediaannya di Perpustakaan Fakultas Geografi UGM. Berkala Ilmu Perpustakaan dan Informasi, Volume III (6): 1-13.

Junandi, S. 2010. Analisis sitiran artikel jurnal luar negeri pada laporan penelitian di Lembaga Penelitian dan Pengabdian kepada masyarakat UGM yang dibiayai Badan Litbang Pertanian Departemen Pertanian tahun 2007. Skripsi. UIN SUKA Yogyakarta.

Kurniawan, F.D. 2012. Analisis sitiran terhadap Jornal Fihris tahun 2008 dan ketersediaan koleksi di Perpustakaan UIN Sunan Kalijaga Yogyakarta. (http://digilib.uin-suka.ac.id / 7280/ Diunduh 5 Mei 2013.

Kamus Besar Bahasa Indonesia. 1988. Jakarta: Balai Pustaka.

Kerlinger, F.N. 1990. Asas-asas Penelitian Behavioral. Edisi 3. Penerjemah: Landung R. Simatupang. Yogyakarta: GadjahMadaUniversity Press.

Lasa HS. 1998. Kamus Istilah Perpus-takaan. Yogyakarta: Gadjah Mada University Press.

2005

Manajemen

Perpustakaan. Yogyakarta: Gama Media.

Lembaga Ilmu Pengetahuan Indonesia (LIPI). 1983. Keputusan Ketua LIPI No.81/Kep/H.10/1983 tentang Tata Tertib Publikasi. Jakarta: LIPI. 
Rousseau, R. 2002. "Journal Evaluation: Technical and Practical Issues", Library Trends. Vol. 50, Winter (3):418-439. , 2007. Dasar-dasar Ilmu Perpustakaan dan Informasi, Yogyakarta: Jurusan Ilmu Perpustakaan dan Informasi Fakultas Adab UIN Sunan Kalijaga.

Sulistyo-Basuki. 1994. "Analisis Sitiran, Kositiran dan Pasangan Bibliografis (Citation Analysis, Co-Citation, and Bibliographic Coupling)". Dalam Sosok Pribadi Unik Mastini Hardjoprakosa. Mochtar, K. dkk (Ed). Jakarta: Yayasan Kawedi. 1995. Komunikasi Ilmiah dan Manfaatnya bagi Tenaga Pengajar dan Mahasiswa. Sebuah makalah dalam Seri Pengembangan Perpustakaan: Mempertanyakan Keberadaan Perpustakaan Kita. Semarang: Soegijapranata Catholic University Press.
2002.

"Bibliometrika, Sainsmetrika dan Infrometrika". Kumpulan Makalah Kursus Bibliometrika. Depok: Masyarakat Informe-trika Indonesia. 20-23 Mei 2002.

Wikipedia, The Free Encyclopedia. Dalam (http://en.wikipedia.org/ wiki/Editorial board). Diakses 23 Maret 2008.

Zulaikha, S.R. 2002. "Kajian Analisis Sitasi terhadap Skripsi Mahasis-wa IAIN Sunan Kalijaga di UPT Perpustakaan UIN Sunan Kalijaga Yogyakarta (Suatu Evaluasi Keterpakaian Koleksi Perpustakaan Ditinjau dari Analisis Sitasi". (Tesis). Yogyakarta: Program Pascasarjana Universitas Gadjah Mada 